\title{
Herpes simplex virus and the nervous system
}

\author{
P. G. E. KENNEDY \\ M.D., Ph.D., M.R.C.P. \\ Department of Neurological Sciences, St Bartholomew's Hospital, West Smithfield, London EC1
}

\section{Introduction}

Interest in herpes simplex virus (HSV) has increased considerably over the last few years, largely as a result of a more general awareness of the possible association between HSV-2 and cervical cancer and the increasing frequency of sexual transmission of HSV-2. Of less general interest is the affinity of HSV for nervous tissues and its ability to cause a variety of neurological diseases. That HSV can remain latent within neural tissues is well recognized (Baringer, 1975). An intriguing question is how the relatively rare acute neurological syndromes, such as HSV encephalitis and meningitis, are related to the carriage of latent HSV which is so widespread in human individuals.

HSV is a DNA virus and is one of the four human herpes viruses (the others being varicella-zoster virus, cytomegalovirus and Epstein-Barr virus). It has a molecular weight of $99 \pm 5 \times 10^{6}$ daltons (Roizman, Spear and Kieff, 1973). There are two closely related antigenic subtypes of HSV: HSV-1 and HSV-2 which differ in their biological, clinical and epidemiological patterns (Nahmias and Roizman, 1973; Kieff, Bachenheimer and Roizman, 1971; Kieff et al., 1972). There is approximately $50 \%$ homology between the DNAs of HSV-1 and HSV-2 (Kieff et al., 1972).

HSV-1 usually infects non-genital areas, causing blisters in the mouth and lips, but it may also infect the skin of the upper part of the body, the respiratory and gastrointestinal tracts and the eyes (Nahmias and Roizman, 1973). Moreover, it is now recognized that HSV-1 infects genital sites (Chang, 1977; Wolontis and Jeansson, 1977). For example, in the study carried out by Wolontis and Jeansson (1977), HSV-1 was responsible for $15 \%$ of genital infections of all patients studied; HSV-2 accounted for the remaining $85 \%$ of cases. The type of HSV isolated appeared to depend on the age of the patient, with the highest rates of genital isolation of HSV-1 (30\%) being found in the 15-24 year age group. HSV-2 infects primarily the urogenital tract and the skin below the waist (Johnson, 1982). The mode of transmission of HSV-1 is by respiratory, salivary or sexual contact, whereas HSV-2 is transmitted mainly by sexual contact.
Both HSV-1 and HSV-2 are capable of infecting the human nervous system. The particular neurological syndrome caused by HSV depends on a variety of factors including the age and immune status of the host, and socio-economic considerations are also important (Nahmias and Roizman, 1973). This article will provide an overview of the subject which will be considered from four standpoints:

(1) HSV and clinical neurological disease;

(2) Latency of HSV in human nervous tissues;

(3) Experimental HSV latency in animal nervous tissues;

(4) Mechanisms involved in HSV latency.

\section{HSV and clinical neurological disease}

The most important neurological disease caused by HSV is an acute encephalitis which is the commonest type of fatal sporadic acute encephalitis occurring in man (Finelli, 1975). HSV encephalitis has a prevalence of 1 case per million per year (Whitley et al., 1982). Encephalitis due to HSV-1 occurs at all ages (Johnson, 1982), whereas HSV-2 encephalitis is usually restricted to neonates in whom it occurs as part of a disseminated infection. However, a case of HSV-2 encephalitis occurring in a renal transplant recipient as part of a disseminated HSV-2 infection has been described (Linnemann et al., 1976). The incidence of a history of 'cold sores' in patients with HSV encephalitis is no different from that seen in the rest of the population (approximately 25\%) (Johnson, 1982). The mortality rate of $\mathrm{HSV}$ encephalitis in untreated cases is about $50 \%$, and approximately $50 \%$ of the survivors remain with considerable disability (Johnson, 1982). The disease is almost always localized to the orbito-frontal and temporal lobes which show haemorrhagic necrosis, and this localization is often unilateral contrasting with the neonatal encephalitis which produces a diffuse pathology (Finelli, 1975; Johnson, 1982). Both grey and white matter are involved in the inflammatory process (Johnson and Mims, 1968).

It has been suggested that the unique anatomical localization of HSV encephalitis may be a conse- 
quence of virus entry by the olfactory pathway with subsequent spread along the base of the brain (Johnson and Mims, 1968). An alternative theory was proposed by Davis and Johnson (1979) who suggested that HSV encephalitis may result from virus spread from the trigeminal ganglion which is known to harbour latent HSV in normal individuals (Baringer, 1975; Warren et al., 1977); this point will be discussed later in this article. Evidence for the earlier view has recently been provided by Esiri (1982) in her immunohistological study of the distribution of HSV antigens in 29 patients dying of HSV encephalitis. HSV antigens were found mainly in the medial and inferior temporal lobes, hippocampus, amygdaloid nucleus, olfactory cortex, insula and cingulate gyrus. A significant observation was that viral antigens were detected in the glial cells of the olfactory tract but not in the trigeminal pathways. These observations supported the view that the route of HSV infection in this disease is via olfactory rather than trigeminal pathways.

Whitley et al. (1982) have recently used the technique of DNA restriction enzyme analysis to study the DNAs of HSV isolates from eight patients with HSV encephalitis. Isolates were obtained from oral and labial sites and from the brains of these patients. The authors concluded that patients with a combination of oro-labial HSV and HSV encephalitis may be infected with two different herpes simplex viruses and that the encephalitis may be a consequence of a primary herpetic infection but could also follow reactivation of latent HSV genomes; reinfection by a second virus may also be a factor in the pathogenesis of the encephalitis.

Johnson, Olson and Buescher (1968) pointed out that the only definitive methods of diagnosing HSV encephalitis are by isolation of virus from the brain or cerebrospinal fluid (CSF) or by demonstration of HSV antigens in central nervous system (CNS) cells using immunofluorescence techniques. They also commented that it is most unusual to make a definitive diagnosis of non-fatal HSV encephalitis without recourse to brain biopsy. The importance of obtaining a cerebral biopsy from the clinically involved area has also been emphasized (Johnson, 1982).

Successful treatment of HSV encephalitis is dependent on early diagnosis. Whitley et al. (1977) found that adenosine arabinoside (vidarabine) was more effective than placebo administration in biopsyproven cases of HSV encephalitis. The importance of early instigation of drug treatment in improving both survival and morbidity rates has also been demonstrated (Whitley et al., 1981). However, vidarabine is not free of toxic effects (Johnson, 1982). More recently, a new drug, the nucleoside analogue acyclovir (acycloguanosine) (Elion et al., 1977) has been investigated (Saral et al., 1981; Field and Wild 1981) and is now the drug of choice for treatment of HSV encephalitis. Acyclovir is activated specificali in HSV-infected cells and has the great advantages of being non-toxic to normal uninfected cells, and of inhibiting selectively the HSV-specific DNA polsmerase and thymidine kinase (Miranda et al., 1979; Johnson, 1982). Most clinicians in the Unite Kingdom do not routinely perform brain biopsies case of suspected HSV encephalitis. It is the authoms opinion that the advent of acyclovir has made sucho position more tenable. It seems justified to treat all suspected cases of HSV encephalitis with acyclovir any early stage of the illness without recourse to brazn biopsy in view of the drug's remarkable lack toxicity and probably efficacy. HSV causes a number of neurological syndromes in addition to enceph $\frac{G}{2}$ litis. The ability of HSV-2 to cause aseptic meningitis in both newborns and adults is well-establisheg (Craig and Nahmias, 1973), and in such cases the virus has been isolated from either the CSF (Stalder et al., 1973) or the peripheral blood (Craig and Nahmias, 1973). HSV-1 has been recovered from the CSF of a patient with ascending myelitis (Klastersky et al., 1972), and Craig and Nahmias (1973) described a case of ascending myelitis pro ably due to HSV-2 which was isolated from vulval lesions. A lumbosacral radiculomyelopathy ङ10 drome has been described in patients with ge HSV-2 infections (Caplan, Kleeman and Berg, 187 and Handler et al. (1983) reported a case of HSY radiculomyelopathy which responded to adenosine arabinoside.

It has been suggested that HSV has also bee associated with congenital malformations of the CNS (South et al., 1969; Johnson, 1982) but definitio evidence is lacking. HSV has been implicated in cases of trigeminal neuralgia (Finelli, 1975), facial nert palsy (McCormick, 1972) and temporal lobe epilepsy (Oxbury, Mathews and MacCallum, 1972), but these various conditions it is not clear whether direct cause-and-effect relationship exists between the diseases and HSV.

\section{Latency of HSV in human nervous tissues}

The ability of HSV to produce recurrent infections in man is well known (reviewed by Baringer, 1975. For example, spontaneous reactivation of HSV-1 i the form of 'cold sores' on the lips may be produced by a variety of factors including sunlight, stres fever, skin trauma and X-irradiation (Wildy, Fielg and Nash, 1982). Recurrent infections of the urogent tal tract with HSV-2 are also well recognizes (Johnson, 1982).

It is now generally accepted that HSV remains in latent form in human sensory ganglia. Early evidence 
for this was provided by Cushing (1904) who noted herpetic eruptions in two patients who had undergone the operation of extirpation of the trigeminal ganglion for severe trigeminal neuralgia. In both cases he observed that subsequently herpetic eruptions developed only outside the areas which had been rendered anaesthetic by the extirpation, indicating a link between the trigeminal ganglion and the development of the herpetic eruptions. These observations following trigeminal operations have been confirmed in a number of subsequent reports (Baringer, 1975). In his classic paper, Goodpasture (1929) surmised that $\mathrm{HSV}$ resides in a latent state in nervous tissues 'perhaps primarily within nerve cells of the ganglia'. Since then the evidence for this early concept has steadily increased, particularly over the last decade. A further indication that the nervous system is involved in HSV recurrences is that herpetic lesions are frequently heralded by sensory symptoms such as pain and paraesthesiae in the affected cutaneous areas (Baringer, 1975).

There have now been a number of reports of the isolation of HSV from human ganglia. The first report of the isolation of HSV from human trigeminal ganglia was that of Bastian et al. (1972). HSV was isolated from a trigeminal ganglion obtained at autopsy from one out of 22 patients without clinical evidence of active herpetic disease and one patient with malignant lymphoma with herpes zoster on the abdomen and possible oral herpes simplex. The technique used was one of co-cultivation of ganglion explants with monolayer cultures of susceptible cells; cytopathic effects were seen three weeks after culture.

A number of other workers have employed similar techniques using explanted trigeminal ganglia obtained at autopsy to show that HSV is present in a high proportion (up to approximately $50 \%$ ) of human trigeminal ganglia (Baringer and Swoveland, 1973; Plummer, 1973; Forghani, Klassen and Baringer, 1977; Warren et al., 1977). Baringer and Swoveland (1973) also showed that HSV could not be isolated from the trigeminal nerve or root of these patients. The virus isolated in these experiments has been shown to be HSV-1 (Plummer, 1973; Forghani et al., 1977; Warren et al., 1977). In addition, Baringer (1974) succeeded in isolating HSV-2 from human sacral ganglia obtained at autopsy using very similar explant culture methods. Forghani et al. (1977) isolated HSV-2 from eight out of 68 human sacral ganglia, and isolated HSV-1 from one out of 25 thoracic ganglia, one out of 68 sacral ganglia and 44 out of 90 trigeminal ganglia. These workers also showed that simultaneous latent infection with HSV1 and HSV-2 can occur in the same individual, and that antibody is produced to each virus independently. These observations were later extended by Warren et al. (1978) who isolated HSV-1 from post- mortem human superior cervical and vagal ganglia in addition to trigeminal ganglia.

More recently, molecular biological techniques have been employed to study HSV latency in human nervous tissues. For example, Sequera et al. (1979) used DNA hybridization techniques to show that HSV-1 nucleic acid sequences were present in postmortem brain smears from three out of four elderly patients with chronic psychiatric illness and neuropathological changes, but not from two patients who had acute psychiatric episodes and minimal abnormal histological change. It was reported by Fraser $e t$ al. (1981) that HSV-1 nucleic acid sequences were detectable in six out of 11 human brain DNA samples. The positive samples came from three normal individuals and three patients with multiple sclerosis. However, as in the study by Sequera et al. (1979), the number of patients studied was small. In addition, only small amounts of brain tissue were sampled, although tissues from several different sites were obtained.

Lonsdale et al. (1979) analyzed the polypeptide and DNA restriction enzyme profiles of spontaneous HSV-1 isolates from the trigeminal, superior cervical and vagus ganglia of a number of individuals. Virus isolates from the ganglia of different individuals could almost always be distinguished from one another. The authors concluded that a single virus strain infects each individual initially and virus produced from this infection then remains in latent form in different cells in the same ganglion and also in different ganglia. Brown et al. (1979) have used temperature-sensitive $(t s)$ HSV-1 mutants as genetic probes to detect latent HSV information in human ganglia. A ts mutant has a mutation which renders it unable to produce virus progeny at $38.5^{\circ} \mathrm{C}$ ('nonpermissive temperature') although the virus can still replicate normally at $31^{\circ} \mathrm{C}$ ("permissive temperature'), contrasting with wild-type $(t s+)$ virus which can replicate at both temperatures (Subak-Sharpe, 1973). Explant cultures of human trigeminal, superior cervical and vagus ganglia that had failed to release HSV spontaneously were superinfected with a range of HSV-1 ts mutants at both permissive and non-permissive temperatures. The ganglia from eight out of 14 individuals which had consistently failed to release virus spontaneously were found to contain HSV information that could be detected by complementation or 'rescued' following superinfection with HSV-1 ts mutants (Brown et al., 1979).

\section{Experimental HSV latency in animal nervous tissues}

The ability of HSV to remain in latent form in sensory ganglia of animals is now well established (Baringer, 1975). Stevens and Cook (1971) were the first to show that HSV can establish a latent infection 
of spinal dorsal root ganglia of mice after the latter had been previously inoculated with virus in the footpad. Infectious virus was detected when these ganglia were explanted but only after they had been maintained as organ cultures in vitro for some days. Neither viral antigens nor virions were detected by electron microscopy or immunofluorescence in ganglia in vivo, and virus was not detected in nervous tissues other than ganglia. Subsequently, Stevens, Nesburn and Cook (1972) used the same organ culture techniques to show that HSV induces a latent infection in trigeminal ganglia of rabbits after the virus had been inoculated in the corneas of these animals. Nesburn, Cook and Stevens (1972) extended these observations by showing that latent HSV could be recovered in ganglia explanted from such rabbits as long as $\mathbf{9 . 5}$ months after initial corneal infection.

HSV has been shown to establish latency in other neural tissues. For example, Knotts, Cook and Stevens (1973) were able to establish latency in the brainstems of rabbits after corneal inoculation of the virus and in the spinal cords of mice after footpad inoculation. Latent HSV has been recovered from the sensory ganglia, brains and adrenal medulla of mice following intravenous inoculation of virus (Cook and Stevens, 1976). In the latter experiments HSV could not be isolated from any non-neural tissues. In addition, Price, Katz and Notkins (1975) were able to produce HSV latency in the superior cervical ganglia of mice following inoculation of HSV into the anterior chamber of the eyes of these animals. When corneal inoculation of HSV was carried out virus persisted in autonomic ganglia for over 1 year following inoculation in some cases.

It is now widely thought that in these experimental models of HSV latency in the peripheral nervous system, the most important route of virus spread from the initial site of inoculation to the ganglia is via transport within the axis cylinders (Wildy et al., 1982; Baringer, 1975). Although there is much evidence for this view (Wildy, 1967; Kristensson, Sheppard and Bornstein, 1974; and see Wildy et al., 1982), the precise form in which the virus is transported within axons has yet to be established.

There is considerable evidence to suggest that latent HSV is harboured in the neuronal cell body (Cook, Bastone and Stevens, 1974; McLennan and Darby, 1980; Wildy et al., 1982). This view is supported by observations that latent HSV is recoverable from spinal ganglia but not the adjacent roots (Baringer and Swoveland, 1973; Cook et al., 1974). However, Warren et al. (1982) have recently reported the isolation of HSV-1 from the trigeminal nerve roots from five out of 18 human cadavers, suggesting that latent HSV in humans may not be confined to the sensory and autonomic ganglia. It is possible, however, that occasional neurones may be present in the trigeminal nerve roots and may be the source of latent HSV. Cook et al. (1974) used immunofluores. cence, electron microscopy and autoradiography their study of latently infected ganglia to show that viral antigens were induced in neurones, virus particles were seen only in neurones, and neurones were the first cells to synthesize viral DNA.

More definitive evidence for the neuronal localizas tion of latent HSV was provided by McLennan and Darby (1980) who produced latent infection of the cervical ganglia of mice using a $t s$ mutant of HSt Reactivation of this mutant virus at the non-permissive temperature showed that HSV antigens were only present in neurones. Such cells were abortivety infected with HSV at the non-permissive temper\&్ ture, thereby eliminating the possibility of spread of virus with the development of secondary foci of infection. There findings provided unambiguouzs evidence that the neurone is the site of latent HSP. Further definitive evidence for the role of the neurone in harbouring latent HSV was recent. provided by Kennedy, Al-Saadi and Clements (1988) who prepared dissociated cell cultures from mouse dorsal root ganglia which had been latently infected with HSV. Using cell-type-specific markers (Ken nedy, 1982) and immunofluorescence techniques $\frac{\text { qt }}{2}$ was shown that latent HSV reactivates first in neurones and infectious virus was released and ont8 subsequently spread to other cell types. Reactiva ifiof differs from acute lytic infection with HSV in which neurones appear to be more resistant to the vitus compared with other neural cell types in bot humans (Kennedy, Clements and Brown, 1983) angey mice (Kennedy et al., 1983).

\section{Mechanisms involved in HSV latency}

The mechanisms underlying the induction of the latent state, the maintenance of HSV latency and of virus reactivation are currently not understood. Three specific aspects of HSV latency will considered:

(a) Immune mechanisms;

(b) Latency in non-neural sites;

(c) The state of the viral genome in HSV latency.

Immune mechanisms. Immune mechanisms in the host play a role in HSV latency (Wildy et al., 1982 Stevens and Cook (1974) provided evidence suggest that anti-viral IgG is involved in maintaining latent HSV infections in the sensory ganglia of mice Following transplantation of latently infected mous spinal ganglia into latently infected and uninfectéd mice, it was found that in the former (immune mice) reactivation of $\mathrm{HSV}$ from the transplanted ganglio? was minimal compared with that observed in the non-immune mice. The IgG appeared to inhibit intraneural viral DNA and antigen synthesis, restrict 
ing the spread of infectious virus. However, more recent studies by Sekizawa et al. (1980) using mice passively immunized against HSV prior to inoculation have indicated that neutralizing antibody is not necessary to maintain the latent state. In addition, Kennedy et al. (1983) observed that the presence of neutralizing antibody did not modify the process of reactivation of HSV in dissociated cell cultures of latently infected mouse spinal ganglia. However, the role of non-neutralizing antibody in the latency process has yet to be established (Wildy et al., 1982). Moreover, it is known that the host's immunological response to HSV does restrict the number of cells in spinal ganglia that become infected with the virus (Walz, Yamamoto and Notkins, 1976).

Although anti-HSV IgG is probably not an important factor in maintaining HSV latency, cell-mediated immune response of the host appear to play a role in HSV recurrences (Wildy et al., 1982), and a variety of $T$ cell protective responses are involved in both primary HSV infections and during recurrences [for a detailed account of cell-mediated immunity in HSV latency, the reader is referred to the excellent review by Wildy et al. (1982)].

Latency in non-neural sites. Any theory of HSV latency must take into account observations that HSV can be isolated from the skin at the site of inoculation of latently infected guinea-pigs (Scriba, 1977). Relevant in this context are the clinical observations of Hoyt and Billson (1976) who reported recurrent HSV infections in individuals who had sustained 'blow out' fractures involving severance of the nerves to the appropriate skin. Moreover, Hill, Harbour and Blyth (1980) were able to isolate HSV from the ears of 8-9\% of clinically normal latently infected mice by culturing the skin in vitro. Al-Saadi, Clements and Subak-Sharpe (1983) have recently shown that in latently infected mice wildtype HSV-2 and some HSV-2 ts mutants can be recovered from the footpad at the side of inoculation. Possible explanations for the ability to recover HSV from these peripheral sites include the following; (i) latent HSV infection is established in these sites; (ii) reactivation of latent HSV occurs in the spinal ganglion and the virus subsequently travels via nervous pathways to the skin; or (iii) virus persistence occurs in the skin, i.e. virus is continually released (Al-Saadi et al., 1983). The latter workers consider that the establishment of a latent infection in the peripheral site of virus inoculation is probably the most likely explanation.

The state of the viral genome in HSV latency. It is not known whether the HSV genome is integrated into the host neuronal DNA or permanently retained within the cell in another way during latency (the 'static' mechanism), or whether a 'dynamic' state exists in which latent infection is maintained by a constant low level of replication of infectious virus in neuronal cells (Roizman, 1965; Stevens and Cook, 1973; Wildy et al., 1982). Although a static mechanism is probably more likely, both processes may be involved in latency (Wildy et al., 1982).

HSV $t s$ mutants have been used extensively to study the mechanisms involved in latency. Reference has already been made to their use as genetic probes to detect latent HSV information in human ganglia (Brown et al., 1979), and to study the cellular localization of latent $\mathrm{HSV}$ in vivo (McLennan and Darby, 1980). Lofgren et al. (1977) and Watson et al. (1980) have shown that HSV ts mutants differ in their capacity to establish latent infections in the nervous tissues of mice. The work of Clements and SubakSharpe (1983) and Al-Saadi et al. (1983) has extended such observations by studying the ability of a wide range of $\mathrm{HSV}-1$ and $\mathrm{HSV}-2$ ts mutants to establish latency in mouse spinal ganglia. By a systematic study of the behaviour of $t s$ mutants using recent molecular biological techniques it should be possible eventually to define the specific region(s) of the HSV genome which are involved in the initiation and maintenance of the latent state. Modification of the viral genome by means of genetic engineering techniques may then be possible with obvious clinical therapeutic implications.

\section{Conclusions}

HSV causes a variety of neurological conditions, the most important of which is HSV encephalitis, a disease which has a high mortality and morbidity. Recent advances in anti-viral therapy, in particular the introduction of the drug acyclovir, are likely to improve the outcome of patients with HSV encephalitis and these other conditions. Both HSV-1 and HSV-2 have the ability to produce latent infections in the nervous tissues of man and experimental animals, and the neurone is the cell which harbours the latent virus. The molecular mechanisms underlying the initiation and maintenance of the latent state and of virus reactivation are not yet understood. Cellular immune mechanisms in the host appear to be more important than humoral immunity in the latency process. The state of the viral genome in latently infected cells is not known. The increasing use of molecular biological techniques and HSV mutants is likely to enhance our understanding of the molecular determinants of latency and an understanding of the latter is likely to have important implications for the therapy of diseases caused by HSV.

\section{Acknowledgments}

I am indebted to Dr G. B. Clements for helpful discussions. Personal work referred to in this article was carried out with the financial support of the British Multiple Sclerosis Society. 


\section{References}

Al-SaAdi, S.A., Clements, G.B. \& Subak-Sharpe, J.H. (1983) Viral genes modify HSV latency in mouse footpad and sensory ganglia. Journal of General Virology, 64, 1175.

BARINGER, J.R. (1974) Recovery of herpes simplex virus from human sacral ganglions. New England Journal of Medicine, 291, 828.

BARINGER, J.R. (1975) Herpes simplex virus infection of nervous tissue in animals and man. Progress in Medical Virology, 20, 1.

BARINGER, J.R. \& SWOVELAND, P. (1973) Recovery of herpes simplex virus from human trigeminal ganglions. New England Journal of Medicine, 288, 648.

Bastian, F.O., Rabson, A.S., Yee, C.L. \& Tralka, T.S. (1972) Herpes virus hominis: Isolation from human trigeminal ganglion. Science, 178, 305.

Brown, S.M., Subak-Sharpe, J.H., Warren, K.G., WrobLEWSKA, Z. \& KOPROWSKI, H. (1979) Detection by complementation of defective or uninducible (herpes simplex type 1) virus genomes latent in human ganglia. Proceedings of the National Academy of Sciences, U.S.A., 76, 2364.

CAPLAN, L.R., KLEEMAN, F.J. \& BERG, S. (1977) Urinary retention probably secondary to herpes genitalis. New England Journal of Medicine, 279, 920.

ChANG, T.W. (1977) Genital herpes and type 1 herpes virus hominis. Journal of the American Medical Association, 238, 155.

ClementS, G.B. \& SUBAK-SHARPE, J.H. (1983) Recovery of herpes simplex virus type $1 \mathrm{ts}$ mutants from the dorsal root ganglia of mice. In: Progress in Brain Research (Eds. P. O. Behan and V. Ter Meulen). Elsevier, Amsterdam (in press).

COOK, M.L., BASTONE, V.B. \& STEVENS, J.G. (1974) Evidence that neurons harbour latent herpes simplex virus. Infection and Immunity, 9, 946.

CooK, M.L. \& StevenS, J.G. (1976) Latent herpetic infections following experimental viraemia. Journal of General Virology, 31, 75.

CRaig, C.P. \& Nahmias, A.J. (1973) Different patterns of neurologic involvement with herpes simplex virus types 1 and 2 : Isolation of herpes simplex virus type 2 from the buffy coat of two adults with meningitis. Journal of Infectious Diseases, 127, 365.

CusHING, H. (1904) Perineal zoster with notes upon cutaneous segmentation postaxial to the lower limb. American Journal of the Medical Sciences, 127, 375.

DAVIS, L.E. \& JoHNSON, R.T. (1979) An explanation for the localisation of herpes simplex encephalitis? Annals of Neurology, $5,2$.

Elion, G.B., Furman, P.A., Fyfe, J.A., Miranda, P. DE, BeauCHAMP, L. \& SCHAEFFER, H.J. (1977) Selectivity of action of an anti-herpetic agent, 9-(2-hydroxyethoxymethyl) guanine. Proceedings of the National Academy of Sciences, U.S.A., 74, 5716.

ESIRI, M.M. (1982) Herpes simplex encephalitis-An immunohistological study of the distribution of viral antigens within the brain. Journal of the Neurological Sciences, 54, 20.

FIELD, H.J. \& WILDY, P. (1981) Recurrent herpes simplex: The outlook for systemic antiviral agents. British Medical Journal, 282, 1821.

FINELLI, P.F. (1975) Herpes simplex virus and the human nervous system: Current concepts and review. Military Medicine, 140, 765.

FORGHANI, B., KLASSEN, T. \& BARINGER, J.R. (1977) Radioimmunoassay of herpes simplex virus antibody: Correlation with ganglionic infection. Journal of General Virology, 36, 371.

FRASER, N.W., LAWRENCE, W.C., WROBLEWSKA, Z., GILDEN, D.H. \& KOPROWSKI, H. (1981) Herpes simplex type 1 DNA in human brain tissue. Proceedings of the National Academy of Sciences, U.S.A., 78, 6461 .

GoOdPaSTURE, E.W. (1929) Herpetic infections with special reference to involvement of the nervous system. Medicine (Baltimore), $7,223$.

Handler, C.E., Perkin, G.D., Fray, R. \& Woinarski, J. (1983) Radioculomyelopathy associated with herpes simplex genitalis treated with adenosine arabinoside. Postgraduate Medical Journ 59, 388.

HiLl, T.J., HaRbouR, D.A. \& BLYTH, W.A. (1980) Isolation herpes simplex virus from the skin of clinically normal mia: during latent infection. Journal of General Virology, 47, 205. C

HoYT, C.S. \& BILLSON, F.A. (1976) Herpes simplex infection after blow out fractures. Lancet, ii, 1364.

JOHNSON, R.T. (1982) Viral Infections of the Nervous System. Raven Press, New York.

JoHNSON, R.T. \& MIMS, C.A. (1968) Pathogenesis of viral infectio음 of the nervous system. New England Journal of Medicine, 278, 23

Johnson, R.T., Olson, L.C. \& BUESCHER, E.L. (1968) Herp庀 simplex virus infections of the nervous system. Archives of Neurology (Chicago), 18, 260.

KENNEDY, P.G.E. (1982) Neural cell markers and their application to neurology. Journal of Neuroimmunology, $2,35$.

KenNedy, P.G.E., Al-SAadi, S.A. \& Clements, G.B. (1983ä Reactivation of latent herpes simplex virus from dissociated identified dorsal root ganglion cells in culture. Journal of Generg. Virology, 64, 1629.

Kennedy, P.G.E., Clements, G.B. \& Brown, S.M. (1983G Differential susceptibility of human neural cell types in culture to infection with herpes simplex virus (HSV). Brain, 106, 101.

KiefF, E.D., BaChenheimer, S.L. \& RoIzMAN, B. (1971) Size composition and structure of the deoxyribonucleic acid of herpis simplex virus subtypes 1 and 2. Virology, 8, 125.

KIEFF, E., HOYER, B., BACHENHEIMER, S. \& ROIZMAN, B. (197ר Genetic relatedness of type 1 and type 2 herpes simplex viruses Journal of Virology, 9, 738.

Klastersky, J., CAPPel, R., SNOECK, M.J., Flament, J. \& THiRY L. (1972) Ascending myelitis in association with herpes simpleg virus. New England Journal of Medicine, 287, 182.

KNOTTS, F.B., COOK, M.L. \& STEVENS, J.G. (1973) Latent herpes simplex virus in the central nervous system of rabbits and mice Journal of Experimental Medicine, 138, 740.

Kristensson, K., ShePPard, R.D. \& Bornstein, M.B. (1974) Observations on uptake of herpes simplex virus in orgas cultures of mammalian nervous tissue. Acta Neuropathologico Berlin, 28, 37.

LiNNEMANN, C.C., First, M.R., AlviRa, M.M., AleXA NDER, J.M \& SCHIFF, F.M. (1976) Herpes virus hominis type 2 mening encephalitis following renal transplantation. American Journal o Medicine, 61, 703.

LOFGREN, K.W., STEVENS, J.G., MARSDEN, H.S. \& SUbaK-SharP $\overrightarrow{\vec{G}}$ J.H. (1977) Temperature sensitive mutants of herpes simplex viru differ in their capacity to establish latent infections in mices Virology, 76, 440.

LoNSDALE, D.M., Brown, S.M., Subak-SharPE, J.H., WarReN, K.G. \& KOPROWSKI, H. (1979) The polypeptide and tho DNA restriction enzyme profiles of spontaneous isolates 으 herpes simplex virus type 1 from explants of human trigemind! superior cervical and vagus ganglia. Journal of General Virolog 43, 151.

MCCORMICK, D.P. (1972) Herpes simplex virus as a cause of Belif palsy. Lancet, $29,93$.

MCLENNAN, J.L. \& DARBY, G. (1980) Herpes simplex virus latency The cellular location of virus in dorsal root ganglia and the fate $\vec{o}$ the infected cell following virus activation. Journal of Generd Virology, 51, 233.

MiRANDA, P. DE, Whitley, R.J., Blum, M.R., KeENEY, R.E Barton, N., Cocchetto, D.M., Good, S., Hemstreet, G.PO KIRK, L.E., PAGE, B.S. \& ElION, G.B. (1979) Acyclovir kinetiçs after intravenous infusion. Clinical Pharmacology and There peutics, 26, 718.

NAHMIAS, A.J. \& RolzMAN, B. (1973) Infection with herpes simplex virus 1 and 2. New England Journal of Medicine, 289, 667.

NeSbURN, A.B., COOK, M.L. \& STEVENS, J.G. (1972) Latent herpe? simplex virus. Isolation from rabbit trigeminal ganglia betwee episodes of recurrent ocular infection. Archives of Ophthalmolog $f_{2}$ 88, 412.

OXbURY, J.M., Matthews, W.B. \& MacCallum, F.O. (1972

.
. 
Herpes simplex and temporal lobe epilepsy. British Medical Journal, 3, 288.

Plummer, G. (1973) Isolation of herpes viruses from trigeminal ganglia of man, monkeys and cats. Journal of Infectious Diseases, $128,345$.

Price, R.W., KATZ, B.J. \& NotKINS, A.L. (1975) Latent infection of the peripheral autonomic nervous system with herpes simplex virus. Nature, 257, 686.

RoIzMAN, B. (1965) An inquiry into the mechanisms of recurrent herpes infections of man. Perspectives in Virology, 4, 283.

Roizman, B., SPEAR, P.G. \& KIEFF, E.D. (1973) Herpes simplex virus I and II. A biochemical definition. Perspectives in Virology, 8, 129.

SARAL, R., BURNS, W.H., LASkin, O.L., SAUTOS, F.W. \& LietMan, P.S. (1981) Acyclovir prophylaxis of herpes simplex virus infections. New England Journal of Medicine, 305, 63.

SCRIBA, M. (1977) Extraneural localisation of herpes simplex virus in latently infected guinea-pigs. Nature, 267, 529.

Sekizawa, T., Oppenshaw, H., WohlenberG, C. \& Notkins, A.L. (1980) Latency of herpes simplex virus in absence of neutralizing antibody: model of reactivation. Science, 210, 1026.

Sequera, L.W., Jennings, L.C., Carrasso, L.H., Lord, M.A., CURRY, A. \& SUTTON, R.N.P. (1979) Detection of herpes simplex viral genome in brain tissue. Lancet, ii, 609.

SOUTH, M.A., Tomkins, W.A.F., MORRIS, C.R. \& RAwLS, W.E. (1969) Congenital malformations of the central nervous system associated with genital type (type 2) herpes virus. Journal of Pediatrics, 75, 13.

Stalder, H., Oxman, M.N., DAwson, D.M. \& Levin, M.J. (1973) Herpes simplex meningitis: isolation of herpes simplex type 2 from cerebrospinal fluid. New England Journal of Medicine, 289, 1296.

STEVENS, J.G. \& COOK, M.L. (1971) Latent herpes simplex virus in spinal ganglia of mice. Science, 173, 843.

STEVENS, J.G. \& COOK, M.L. (1973) Latent herpes simplex virus in sensory ganglia. Perspectives in Virology, 8, 171.

STEVENS, J.G. \& COOK, M.L. (1974) Maintenance of latent herpetic infection: an apparent role for anti-viral IgG. Journal of Immuno$\log y, 113,1685$.

STEVENS, J.G., NeSBURN, A.B. \& CoOK, M.L. (1972) Latent herpes simplex virus from trigeminal ganglia of rabbits with recurrent eye infection. Nature New Biology, 235, 216.

SUBAK-SHARPE, J.H. (1973) The genetics of herpes virus. Cancer Research, 32, 1385.
WaLZ, M.A., Yamamoto, H. \& NotKins, A.L. (1976) Immunological response restricts number of cells in sensory ganglia infected with herpes simplex virus. Nature, 264, 554.

Warren, K.G., Brown, S.M., WroblewSKa, Z., GILDEN, D., KOPROWSKI, H. \& SUBAK-SHARPE, J.H. (1978) Isolation of latent herpes simplex virus from the superior cervical and vagus ganglions of human beings. New England Journal of Medicine, 287, 1068.

Warren, K.G., Devlin, M., Gilden, D.H., Wroblewska, Z., Brown, S.M., SUbaK-SharPe, J.H. \& Koprowski, H. (1977) Isolation of herpes simplex virus from human trigeminal ganglia, including ganglia from one patient with multiple sclerosis. Lancet, ii, 637.

WARREN, K.G., MARUSYK, R.G., LeWIS, M.E. \& JEFFrey, V.M. (1982) Recovery of latent herpes simplex virus from human trigeminal nerve roots. Archives of Virology, 73, 85.

Watson, K., Stevens, J.G., Cook, M.L. \& Subak-Sharpe, J.H. (1980) Latency competence of thirteen HSV-1 temperaturesensitive mutants. Journal of General Virology, 49, 149.

Whitley, R., LAKEMAN, A.D., NAHMias, A. \& Roizman, B. (1982) DNA restriction enzyme analysis of herpes simplex virus isolates obtained from patients with encephalitis. New England Journal of Medicine, 307, 1060.

Whitley, R.J., Soong, S-J., Dolin, R., Galasso, G.J., Chlien, L.T., Alford, C.A. \& THE COllaborative Study Group (1977) Adenosine arabinoside therapy of biopsy-proven herpes simplex encephalitis. New England Journal of Medicine, 297, 289.

Whitley, R.J., SOONG, S-J., Hirsh, M.S., Karchmer, A.W., Dolin, R., Galasso, G., DunNick, J.K., Alford, C.A. \& NIAID Collaborative ANTIVIRAL Study Group (1981) Herpes simplex encephalitis: vidarabine therapy and diagnostic problems. New England Journal of Medicine, 304, 313.

WILDY, P. (1967) The progression of herpes simplex virus to the central nervous system of the mouse. Journal of Hygiene, Cambridge, 65, 173.

WildY, P., FIELD, H.J. \& NASH, A.A. (1982) Classical herpes latency revisited. In: Virus Persistence SGM Symposium 33 (Eds. B. W. J. Mahy, A. C. Minson and G. K. Darby), p. 133. Cambridge University Press.

WolonTIS, S. \& JEANSSON, S. (1977) Correlation of herpes simplex virus types 1 and 2 with clinical features of infection. Journal of Infectious Diseases, 135, 28.

(Received 24 October 1983) 